\title{
The Influence of Hydrogeology to Generation of Hydrogen Sulfide of Low-Rank Coal in the Southeast Margin of Junggar Basin, China
}

\author{
Qigen Deng $\mathbb{D}^{1,2,3}$ Tao Zhang, ${ }^{2}$ Fajun Zhao, ${ }^{1,2}$ Hao Wang, ${ }^{2}$ and Jingping Yin $^{2}$ \\ ${ }^{1}$ State Key Laboratory Cultivation Base for Gas Geology and Gas Control, Henan Polytechnic University, Jiaozuo 454003, China \\ ${ }^{2}$ School of Safety Science and Engineering, Henan Polytechnic University, Jiaozuo 454003, China \\ ${ }^{3}$ State Collaborative Innovation Center of Coal Work Safety and Clean-Efficiency Utilization, Jiaozuo 454003, China
}

Correspondence should be addressed to Qigen Deng; dengqigen@hpu.edu.cn

Received 1 May 2020; Revised 28 May 2020; Accepted 4 June 2020; Published 30 June 2020

Academic Editor: Guozhong Hu

Copyright (C) 2020 Qigen Deng et al. This is an open access article distributed under the Creative Commons Attribution License, which permits unrestricted use, distribution, and reproduction in any medium, provided the original work is properly cited.

\begin{abstract}
The salinity, chemical properties, and migration characteristics of groundwater in coal measures are the key factors that affect the generation, migration, and reservoir of hydrogen sulfide $\left(\mathrm{H}_{2} \mathrm{~S}\right)$ in low-rank coal seams. Taking the Jurassic coal and rock strata in the southeastern margin of the Junggar basin as the research object, according to the hydrogeological characteristics of the coal measures, the region is divided into 4 hydrogeological units. The coalbed methane contains a large number of secondary biogas. Along the direction of groundwater runoff, the salinity and the $\mathrm{pH}$ value increase gradually. The salinity in the hydrogeological units is low; it is not conducive to the propagation of sulfate-reducing bacteria and the formation of hydrogen sulfide of the Houxia, the south of Manasi River, and Hutubi and Liuhuangou area, the western region of the Miquan. The high salinity center and depressions of low water level (hydrodynamic stagnation zone) in the hydrogeological unit of the Liuhuanggou and the Miquan are the main areas for the production and enrichment of $\mathrm{H}_{2} \mathrm{~S}$ in the low-rank coal. The high salinity in water is formed by infiltration, runoff, and drought evaporation. At the same time, the deep confined water environment closed well; in conditions of hydrocarbon-rich, under the action of sulfate-reducing bacteria, bacterial sulfate reduction will occur and hydrogen sulfide formed. According to the circulation characteristics of water bearing $\mathrm{H}_{2} \mathrm{~S}$ in the region, imbricate and single bevel two kind generation and enrichment mode of hydrogen sulfide under the action of hydrodynamic control. The solubility of hydrogen sulfide in pure water and solutions of $\mathrm{NaCl}$ and $\mathrm{Na}_{2} \mathrm{SO}_{4}$ with different molar concentrations was calculated. The $\mathrm{H}_{2} \mathrm{~S}$ solubility of groundwater in coal measures of 4 hydrogeological units was estimated.
\end{abstract}

\section{Introduction}

The Xinjiang Uygur Autonomous region is a domestic coalproducing province with predicted reserves accounting for about $40 \%$ in China. The southeastern margin of Junggar basin is a typical development basin of coalbed methane of inland low-rank coal. Hydrogen sulfide $\left(\mathrm{H}_{2} \mathrm{~S}\right)$ in coalbearing strata in many mining areas is abnormally enriched, particularly serious in the southeastern margin of Junggar basin, such as Urumqi, Changji, and Fukang, and there are many accidents involving death and injury [1]. It is generally believed that $\mathrm{H}_{2} \mathrm{~S}$ can be formed by biochemical degradation in the early peat accumulation, the bacterial sulfate reduction
(BSR) in the peat accumulation period and at the stage of coal formation, thermochemical sulfate reduction (TSR) during coal evolution, and thermal decomposition sulfides (TDS) and magma (volcanic eruption) activity, and it is widely believed that the BSR and TSR are the main origins of $\mathrm{H}_{2} \mathrm{~S}$ in coal and rock seams [1-5]. Bacterial sulfate reduction (BSR) is a metabolic process in which sulfate-reducing bacteria absorb sulfate under the condition of no oxygen reduction, oxidize organic compounds to obtain energy, and reduce sulfate to form hydrogen sulfide. The chemical properties of underground fluids and the characteristics of microbial activity in the groundwater have an important influence on the generation of biogas-bearing hydrogen sulfide in the 
low-rank coal seams; it is the main controlling factors affecting the formation, migration, and reservoir of hydrogen sulfide in low-rank coal seams [6, 7]. Based on the anomalous enrichment of coal and rock strata in the southeastern margin of Junggar basin, this paper analyzes the geological overview of the study area and discusses the effects of salinity of groundwater in coal measures on the formation, migration, and accumulation of $\mathrm{H}_{2} \mathrm{~S}$ in low-rank coal seams. The $\mathrm{H}_{2} \mathrm{~S}$ solubility of water bodies in coal measures was calculated. The research has a certain supporting role in supplementing and improving the causes, distribution characteristics, occurrence rules, and disaster prevention of existing coal mine (coal methane) $\mathrm{H}_{2} \mathrm{~S}$. At the same time, it provides theoretical support for atmospheric environmental pollution control. Furthermore, it provides reference for the exploration and development of low-rank coal seam coalbed methane containing $\mathrm{H}_{2} \mathrm{~S}$ in the southeastern margin of Junggar basin, China.

\section{Regional Geological Survey}

The area is in the binding site of the southern margin of Junggar basin, northern Tianshan Mountain, and Bogda Mountain, China. The coal and rock strata form a series of northwest, northeast east and southeast east linear fault-fracture zones $[8,9]$. The structural division belongs to the southeastern margin of the Junggar basin front fold belt, and most of the surface is covered by the Quaternary strata, and the Jurassic strata are widely exposed. The regional coalfield geological map is shown in Figure 1.

The regional coal-bearing strata are mainly the Badaowan formation of lower Jurassic and the Xishanyao formation of middle Jurassic $[10,11]$. In the early Jurassic, the coal-sedimentary deposits were mainly concentrated in the area of the Fukang-Shuixigou area east of Urumqi, forming the Badaowan formation $\left(J_{1} b\right)$ coal seam. The coal seams are thicker in the east of Urumqi, thinner in the west, and thinner from the bottom up. The coal seam can be collected in a total of 3 15 layers and available in thickness from $45 \mathrm{~m}$ to $66 \mathrm{~m}$, the coal content is $9 \% \sim 11 \%$, and the vitrinite reflectance of coal is generally $0.7 \% \sim 1.0 \%$.

In the middle Jurassic, the coal-riching effect was enhanced, and the rich coal belt migrated westward, appearing in the areas of Fukang, Urumqi, and Manasi, forming the Xishanyao formation $\left(\mathrm{J}_{2} \mathrm{x}\right)$ coal seam. Coal seams become thinner towards the west to east strata, and the best development is in the Urumqi area. The coal seam can be collected in a total of 11 35 layers and available in thickness from $34.1 \mathrm{~m}$ to $151.9 \mathrm{~m}$, and the coal content is $11.7 \% \sim 25 \%$. There are $3 \sim 11$ layers of coal seams that can be collected in total in Toutunhe, with a thickness of $25.6 \mathrm{~m} \sim 52.5 \mathrm{~m}$ which are available and a coal-containing coefficient of $12.8 \% \sim 17.6 \%$. The vitrinite reflectance of coal in the east of Urumqi is generally less than $0.5 \%$, most of which is in the lignite stage. The vitrinite reflectance of coal in the west of Urumqi is generally $0.5 \% \sim 0.7 \%$, mainly in long flame coal and gas coal.

The burial depth of coal seams in the east of Urumqi is shallow, generally less than $800 \mathrm{~m}$, and the coal seams are relatively flat. The buried depth of the coal seam in the west of Urumqi is between $400 \mathrm{~m}$ and $1200 \mathrm{~m}$, which is deeper and deeper from the southern margin to the basin. The formation is steeper; the dip angle is $15^{\circ} \sim 25^{\circ}$ in the west of Urumqi and over $45^{\circ}$ in the Miquan-Fukang area.

\section{Hydrogeology}

The study area has a typical arid and midtemperate continental climate. The evaporation is much larger than the rainfall, and the melting of snow and ice is the main source of coal measure formation water $[6,12]$. According to regional structural characteristics, hydrodynamic parameters of coal measure aquifers, salinity, chemical characteristics of groundwater, etc., and the area can be classified into 4 hydrogeological units: Manasi River-Hutubi River (Ma-Hu), Liuhuanggou area, Miquan area, and Houxia area. This study focuses on two units of hydrogeology: Liuhuanggou area and Miquan area.

The main flow direction of regional groundwater is a centripetal movement from south to north and westward, and it migrates to the deep. In the hydrogeology unit of $\mathrm{Ma}-\mathrm{Hu}$, there are many surface rivers with strong runoff and the alternation between groundwater and surface water is frequent. In the hydrogeological unit of Liuhuanggou, the groundwater is controlled by the south-north small channel anticline, the Kalaza anticline, and the Xishan anticline in the Changji tectonic belt, and the groundwater flows from south to north. In the Miquan hydrogeological unit, the structural extrusion causes the regional groundwater flow to run from Badaowan to the oblique south wing to the core and to the southwest direction along the core. Hydrogeological unit division and groundwater migration characteristics are shown in Figure 2.

\subsection{Effect of Salinity on the Formation of Hydrogen Sulfide}

3.1.1. Composition Characteristics of Regional Coalbed Methane $\delta^{13} \mathrm{C}$. The methane $\delta^{13} \mathrm{C}$ value in the regional coalbed methane mostly falls to $-41.8 \%$ o $-64.7 \%$, generally less than $-50.0 \%$, which is generally light. Among them, the $\delta^{13} \mathrm{C}$ value of methane in the west of Urumqi is more than $-53.3 \%$ o $-62.5 \%$, and the $\delta^{13} \mathrm{C}$ value of methane in the east of Urumqi is more than $-62.1 \%$ o $-50.7 \%$ o $[10,13,14]$. According to the classification of coalbed methane genesis [12], it can be seen that the genetic type of regional coal seam gas has diverse characteristics, both biogenetic features and thermogenic features, but most of them belong to the mixed genetic characteristics.

3.1.2. Characteristics of $\delta^{34} S$ in the Region. The range of various sulfur isotope values ranges from $-14.5 \%$ to $11.6 \%$, which is generally low. Among them, the sulfur isotope value of pyrite in coal is between $8.7 \%$ and $11.6 \%$, with an average of $10.2 \%$; the $\delta^{34} \mathrm{~S}$ of $\mathrm{H}_{2} \mathrm{~S}$ in the coal seam is negative, and the range of values is $-14.5 \% 0 \sim-9.4 \%$, with an average of $-12.3 \%$; the value of $\delta^{34} \mathrm{~S}$ in the coal mine groundwater is $-0.6 \%$; the value of $\delta^{34} \mathrm{~S}$ measured in crude oil in the Houxia area of the regional boundary is $14.17 \%$. The formation of $\mathrm{H}_{2} \mathrm{~S}$ generally exhibits the characteristics of BSR $[2,4,5]$. It can be seen that the regional coalbed methane contains a large amount of secondary biogas, among which methanogens and sulfate-reducing bacteria (SRB) are the main microorganisms of secondary organisms $[2,15]$. 

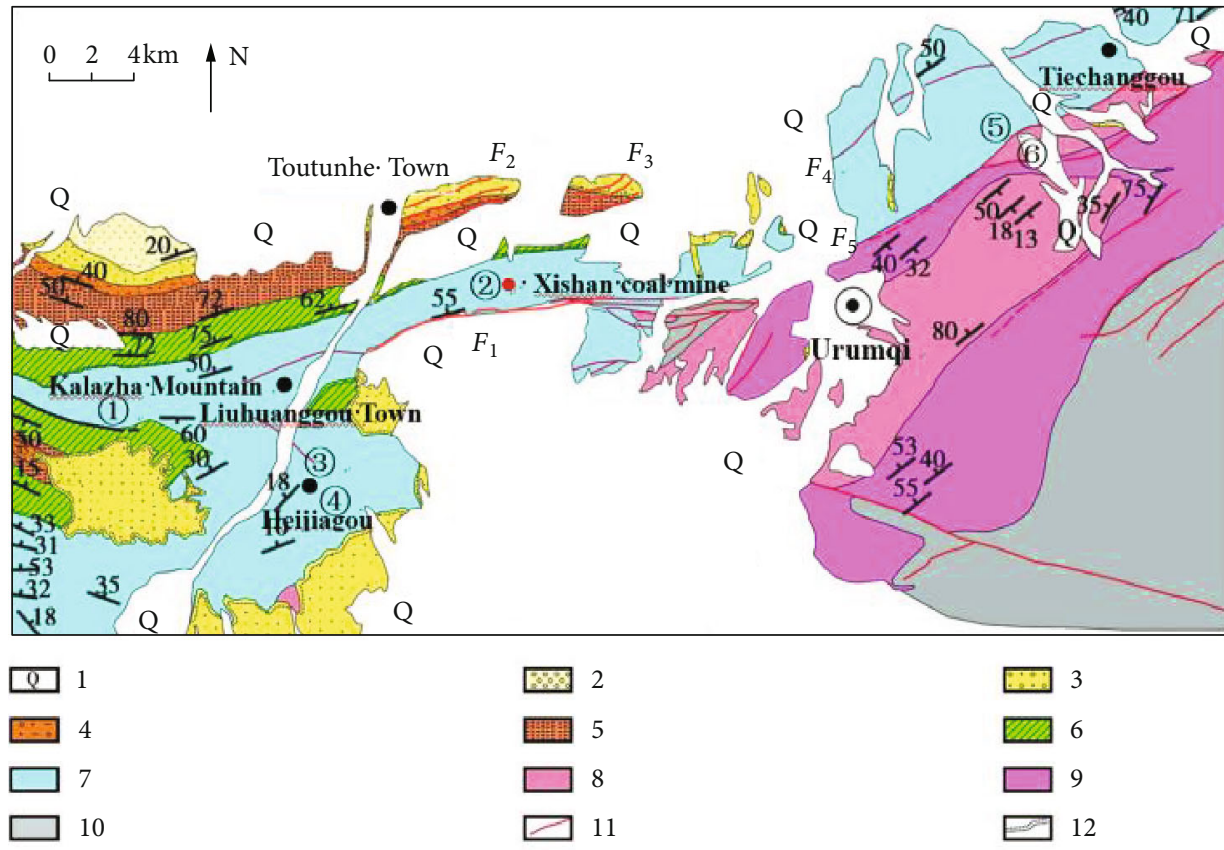

[55 13

FIGURE 1: Map of coal geology in the region: 1: Quaternary, 2: upper section of Changji River Group, 3: lower middle section of Changji River Group, 4: front mountain group, 5: Upper Cretaceous and Lower Tertiary, 6: Lower Cretaceous Tugulu Group, 7: Jurassic, 8: Triassic, 9: Permian, 10: Pre-Permian, 11: fault, 12: unconformity, and 13: rock formation. (1): Kalaza anticline, (2): Xishan anticline, (3): north small channel anticline, (4): south small channel anticline, (5): Qidaowan anticline, and (6): Badaowan anticline. $F_{1}:$ Xishan fault, $F_{2}:$ Wangjiagou fault, $F_{3}$ : Jiujiawan fault, $F_{4}$ : Wanyaogou fault, and $F_{5}$ : Hongshanzui-Baiyanggou fault.

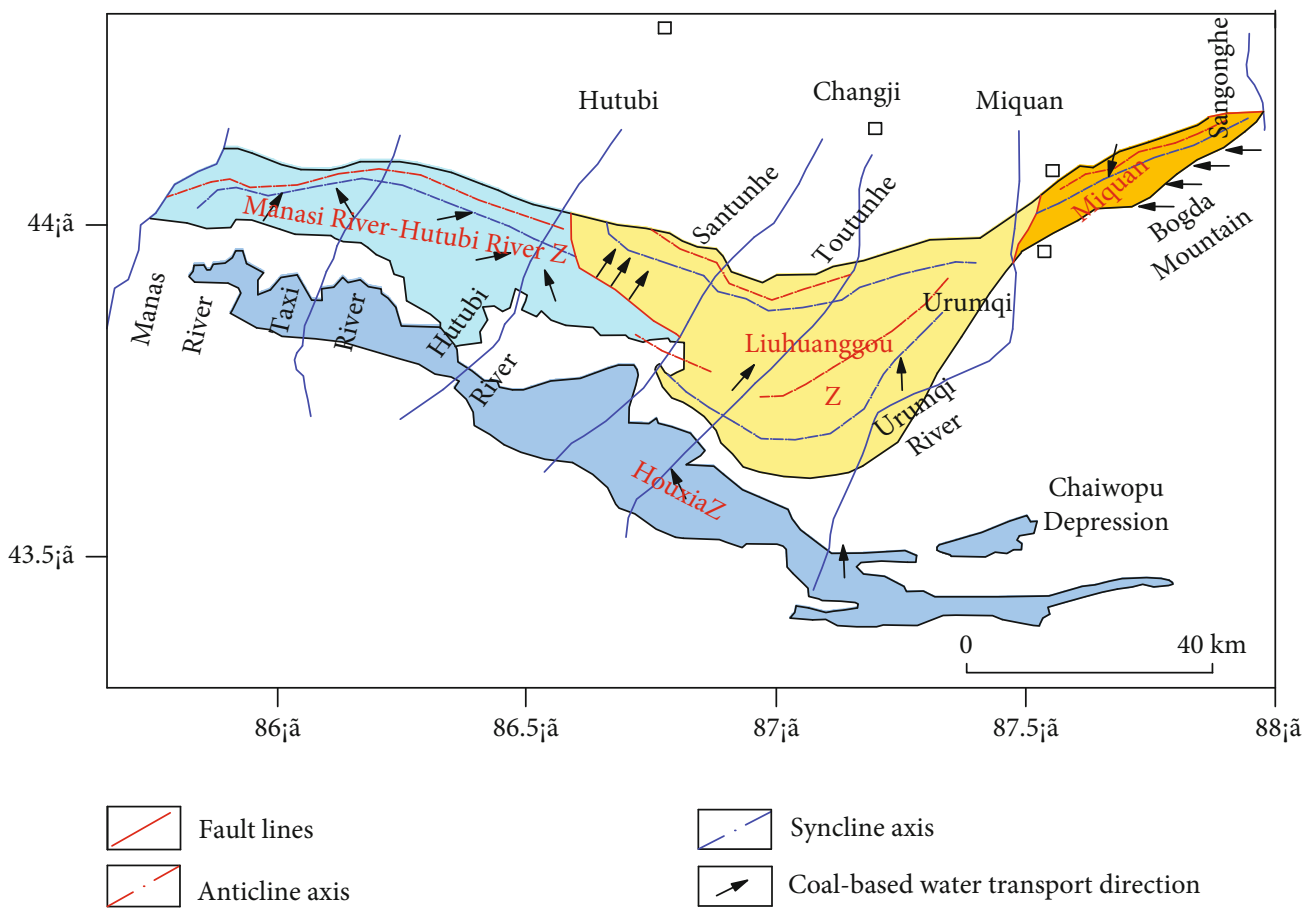

FIGURE 2: Division of hydrogeological units and characteristics of groundwater migration in the region.

3.1.3. Effect of Salinity on the Formation of Hydrogen Sulfide. Total dissolved solid (TDS) is the main controlling factor for microbial reproduction and gas production. When the local layer water TDS is less than $4000 \mathrm{mg} / \mathrm{L}$, the SRB activity is low and the gas production is very small. When the TDS is less than $10^{3} \mathrm{mg} / \mathrm{L}$, the SRB is not easy to survive. As the 
concentration of TDS increases, the SRB will be significantly enhanced and the gas production efficiency will increase. When the TDS exceeds $10000 \mathrm{mg} / \mathrm{L}$, especially in the range of $2 \times 10^{4} \mathrm{mg} / \mathrm{L} \sim 8 \times 10^{4} \mathrm{mg} / \mathrm{L}$, it is very suitable for SRB reproduction. After that, with the increase of salinity, the amount of SRB bacteria decreases greatly. When the TDS reaches $3.5 \times 10^{5} \mathrm{mg} / \mathrm{L}, \mathrm{SRB}$ is difficult to survive. Under reducing conditions when the temperature is $37^{\circ} \mathrm{C}$ and $50^{\circ} \mathrm{C}$, respectively, the effects of different salinity on SRB growth are shown in Figure 3 [16].

The TDS of the groundwater is less than $4000 \mathrm{mg} / \mathrm{L}$ (low salinity) as a region that is not conducive to SRB reproduction and hydrogen sulfide production. The TDS ranged from $4000 \mathrm{mg} / \mathrm{L}$ to $10000 \mathrm{mg} / \mathrm{L}$ (medium salinity), as the area where SRB can reproduce and produce hydrogen sulfide. And the TDS greater than $10000 \mathrm{mg} / \mathrm{L}$ (high salinity) is the most favorable region for SRB reproduction and gas production. The statistical results of coal seam water salinity of the groundwater in coal measures in the four hydrogeological units in the region are shown in Table 1 [17].

The TDS of the four units of the groundwater in coal measures in the area varies greatly. The distribution of salinity has the characteristics of north-south zoning and east-west section. The salinity gradually increases along the direction of groundwater runoff. The low salinity zone is mainly distributed in the southern end of Houxia, Manasi River-Hutubi River, and Liuhuanggou units. This area has frequent alternating hydraulic power, and the reduction and sealing environment is poor. The SRB is not fertile, and the amount of hydrogen sulfide is small. The medium salinity area is distributed in most areas of Manasi River-Hutubi River, Liuhuanggou, and Miquan units. This area is mostly a weak groundwater flow area, and the efficiency of SRB production and hydrogen sulfide production is increased. The high salinity is distributed in the north of the Liuhuanggou unit and the northwest of the Miquan unit. This area has good sealing conditions and is a low water catchment area (hydrodynamic retention area). The SRB is highly proliferated and is the main area for the formation and enrichment of low-rank coal hydrogen sulfide. According to the degree of mineralization and the effect of salinity on SRB reproduction and hydrogen sulfide production, the distribution of salinity and the relationship between SRB reproduction and hydrogen sulfide production can be obtained as shown in Figure 4.

3.2. Influence to Hydrogen Sulfide Formation of Groundwater Chemical Characteristics. The mountains and rivers in the southeast of the region stand, the snow and ice melt, and the groundwater flows from the south to the west and north and gradually flows to the deep. In the direction of runoff, due to the large hydraulic gradient, the alternating action is strong; during the process of infiltration and runoff, dissolution and leaching of calcium feldspar and albite will occur. The possible chemical reactions are shown in Equations (1)-(3) $[5,17]$ :

$$
\begin{gathered}
\mathrm{CaCO}_{3} \cdot 2 \mathrm{Al}_{2} \mathrm{O}_{3} \cdot 4 \mathrm{SiO}_{2} \text { (Anorthite) }+2 \mathrm{CO}_{2}+5 \mathrm{H}_{2} \mathrm{O} \\
\longrightarrow 2 \mathrm{HCO}_{3}^{-}+\mathrm{Ca}^{2+}+2 \mathrm{H}_{4} \mathrm{Al}_{2} \mathrm{Si}_{2} \mathrm{O}_{9}
\end{gathered}
$$

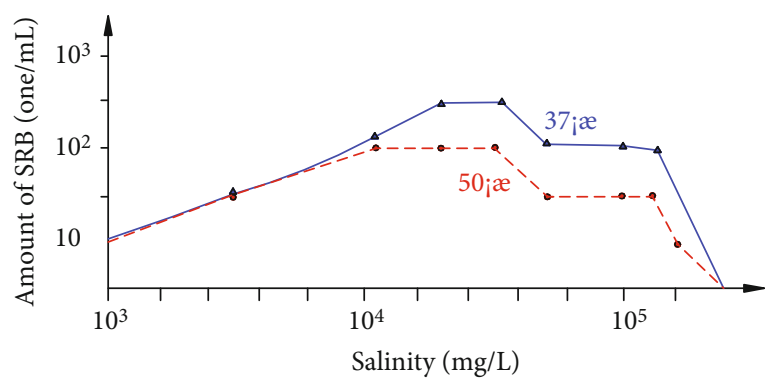

FIgURE 3: The effect of different salinity on the growth of SRB.

$$
\begin{aligned}
& \mathrm{Na}_{2} \mathrm{Al}_{2} \mathrm{Si}_{6} \mathrm{O}_{16}(\text { Albite })+2 \mathrm{CO}_{2}+3 \mathrm{H}_{2} \mathrm{O} \longrightarrow 2 \mathrm{HCO}_{3}^{-} \\
& +2 \mathrm{Na}^{2+}+2 \mathrm{H}_{4} \mathrm{Al}_{2} \mathrm{Si}_{2} \mathrm{O}_{9}+4 \mathrm{SiO}_{2} \\
& \mathrm{CaSO}_{4} \longrightarrow \mathrm{Ca}^{2+}+\mathrm{SO}_{4}^{2-}
\end{aligned}
$$

High salinity water may form under severe drought evaporation. And the deep water environment is well sealed. In the hydrocarbon-rich conditions, under the action of SRB, BSR action will occur and $\mathrm{H}_{2} \mathrm{~S}$ will be formed. The possible reaction formula is shown in Equation (4) [3, 17]:

$$
\sum \mathrm{CH}(\mathrm{C})+\mathrm{SO}_{4}^{2-}+\mathrm{H}_{2} \mathrm{O} \longrightarrow \mathrm{H}_{2} \mathrm{~S} \uparrow+\mathrm{CO}_{2} \uparrow+\mathrm{CO}_{3}^{2-}
$$

A series of BSR promote the formation of calcium carbonate crystals in the water by $\mathrm{CO}_{2}$ and soluble calcium ions, which facilitates the reaction in a positive direction and leads to a decrease in $\mathrm{Ca}^{2+}$ content. From the south to the north of the basin, the cation $\mathrm{Ca}^{2+}$ in the deep pressure water of each coal mine was reduced from $57.8 \%$ to $21.2 \%$ [9], and the chemical characteristics such as $\mathrm{Ca}^{2+}$ and $\mathrm{H}_{2} \mathrm{~S}$ content in the water body met the above rules. $\mathrm{H}_{2} \mathrm{~S}$ is a dibasic acid that is easily soluble in water, and there are two ionization balances in $\mathrm{H}_{2} \mathrm{~S}$ in aqueous solution [5]:

$$
\begin{aligned}
& \mathrm{H}_{2} \mathrm{~S}+\mathrm{OH}^{-} \longleftrightarrow \mathrm{HS}^{-}+\mathrm{H}_{2} \mathrm{O} \\
& \mathrm{HS}^{-}+\mathrm{OH}^{-} \longleftrightarrow \mathrm{S}^{2-}+\mathrm{H}_{2} \mathrm{O}
\end{aligned}
$$

The groundwater is weakly alkaline, and the $\mathrm{pH}$ value is mostly between 7.5 and 9.0. It can be seen that the sulfide in the groundwater in coal measures mainly exists in the form of $\mathrm{H}_{2} \mathrm{~S}$ and $\mathrm{HS}^{-}$.

\subsection{Influence of Groundwater Control on Hydrogen Sulfide} Formation. The high salinity formation water formed by the melting of snow in the southeastern mountains, and the rainfall during the runoff flows into the depression or fault zone in the front of the mountain, and its Quaternary sediments are about $400 \mathrm{~m} \sim 1300 \mathrm{~m}$ thick; a thick layer of loose sand and gravel is piled up. The geological structure of the depression or the basal uplift provides a huge space for the occurrence and migration of groundwater $\left(\mathrm{H}_{2} \mathrm{~S}\right)$. Regional hydrocarbon sources are widely developed. In deep closed environments, groundwater migration is slow or stagnant, SRB is highly proliferated, BSR will occur, and hydrogen sulfide is formed. The regional underground hydrogen 
TABLE 1: TDS distribution of groundwater in coal measures.

\begin{tabular}{lcc}
\hline $\begin{array}{l}\text { Hydrogeological } \\
\text { unit }\end{array}$ & Layer & $\begin{array}{c}\text { Salinity of } \\
\text { groundwater }(\mathrm{mg} / \mathrm{L})\end{array}$ \\
\hline $\begin{array}{l}\text { Manasi River- } \\
\text { Hutubi River }\end{array}$ & $\begin{array}{c}\text { Xishanyao } \\
\text { formation }\left(\mathrm{J}_{2} \mathrm{x}\right)\end{array}$ & $\begin{array}{c}1256-4856 \\
2342\end{array}$ \\
\hline Xishanyao & $3489-17527$ \\
& formation $\left(\mathrm{J}_{2} \mathrm{x}\right)$ & 12925 \\
& Badaowan & $4875-18509$ \\
& formation $\left(\mathrm{J}_{1} \mathrm{~b}\right)$ & 13261 \\
\hline Miquan area & Xishanyao & $4588-15855$ \\
& formation $\left(\mathrm{J}_{2} \mathrm{x}\right)$ & 11029 \\
& Badaowan & $5893-18783$ \\
Houxia area & formation $\left(\mathrm{J}_{1} \mathrm{~b}\right)$ & 12418 \\
\hline
\end{tabular}

sulfide-containing water cycle characteristics can be described as shown in Figure 5.

The regional hydrodynamic gas control is mainly characterized by hydrodynamic closed gas control and hydrodynamic plugging gas control. The east of Urumqi is affected by geological structures, and its groundwater in coal measure monoslanted south wing is recharged by rivers and glacial meltwater, mostly weak runoff areas, and stagnant areas. The sealing conditions are good, and the generated $\mathrm{H}_{2} \mathrm{~S}$ dissolves into the water body or escapes to gas and with the flow of water to the deep part of the coal seam. Meanwhile, the poor continuity of the surrounding rock sand body causes the slowness or the stagnation of the groundwater of the coal-bearing areas. Therefore, the $\mathrm{H}_{2} \mathrm{~S}$ diffusing upward in coal rock will be blocked. At the same time, the slowness of groundwater carries $\mathrm{H}_{2} \mathrm{~S}$ to the deep part and $\mathrm{H}_{2} \mathrm{~S}$ will be blocked, resulting in anomalous enrichment of $\mathrm{H}_{2} \mathrm{~S}$ in coal rock and water. The $\mathrm{H}_{2} \mathrm{~S}$ accumulation model of northward monoclinic is shown in Figure 6 [17].

The west of Urumqi is affected by the Urumqi-Miquan strike-slip fault, and the thrust nappe tectonic belt is developed. It is a kind of fracture with a slip motion moving perpendicular to the fracture surface, and an anticline distribution with a geese shape and imbricate is formed. In the coal outcrops in the southwestern part of the west of Urumqi, water is alternately connected, which is the infiltration area of the formation water. The local zone forms a discharge zone where the hydraulic power alternates strongly. The reduction environment is poor, and SRB reproduction and formation of $\mathrm{H}_{2} \mathrm{~S}$ are not used, and the groundwater body will continuously dissolve and take away the generated $\mathrm{H}_{2} \mathrm{~S}$ during the migration process, eventually leading to $\mathrm{H}_{2} \mathrm{~S}$ dissipation. It is not conducive to the enrichment of $\mathrm{H}_{2} \mathrm{~S}$. In the area of the Xishan coal mine in the northwestern part of the west of Urumqi, the deep hydraulic performance is the retention zone. For $\mathrm{H}_{2} \mathrm{~S}$ generated by the BSR action, some of gas is integrated into the water body and slowly migrated to the deep part; some of it is mixed into the gas of the coal seam and migrates vertically or longitudinally along the gas source at the depression. The distribution of hydrogen sulfide in the regional coal and rock layers is extremely uneven. In the southern part of the west of Urumqi, the hydrodynamic alternating of the shallow strata is relatively strong, and $\mathrm{H}_{2} \mathrm{~S}$ is rarely enriched. However, in the hydrological detention area (Xishan mining area) in the northern part of the west of Urumqi, hydrogen sulfide enrichment is extremely serious. The area of the imbricate $\mathrm{H}_{2} \mathrm{~S}$ formation and aggregation mode is shown in Figure 7.

\section{Hydrogen Sulfide Solubility of Groundwater in Coal Measures}

The solubility of $\mathrm{H}_{2} \mathrm{~S}$ in water is usually affected by temperature, pressure, salinity, water chemistry, and mixed gases [18, 19]. Duan et al. [20,21] and others believe that the solubility of $\mathrm{H}_{2} \mathrm{~S}$ is essentially a gas-liquid equilibrium problem, and the gas-liquid equilibrium problem can be calculated by the equilibrium of $\mathrm{H}_{2} \mathrm{~S}$ in the chemical position $\mu_{\mathrm{H}_{2} \mathrm{~S}}^{v}$ of the gas phase and the chemical position $\mu_{\mathrm{H}_{2} \mathrm{~S}}^{l}$ of the liquid phase. As shown in

$$
\begin{aligned}
\mu_{\mathrm{H}_{2} \mathrm{~S}}^{l}(T, P, m)= & \mu_{\mathrm{H}_{2} \mathrm{~S}}^{l(0)}(T, P)+R T \ln \alpha_{\mathrm{H}_{2} \mathrm{~S}}(T, P, m)=\mu_{\mathrm{H}_{2} \mathrm{~S}}^{l(0)}(T, P) \\
& +R T \ln m_{\mathrm{H}_{2} \mathrm{~S}}+R T \ln \gamma_{\mathrm{H}_{2} \mathrm{~S}}(T, P, m),
\end{aligned}
$$

$$
\begin{aligned}
\mu_{\mathrm{H}_{2} \mathrm{~S}}^{v}(T, P, y) & =\mu_{\mathrm{H}_{2} \mathrm{~S}}^{v(0)}(T)+R T \ln f_{\mathrm{H}_{2} \mathrm{~S}}(T, P, y) \\
& =\mu_{\mathrm{H}_{2} \mathrm{~S}}^{v(0)}(T)+R T \ln y_{\mathrm{H}_{2} \mathrm{~S}}(P)+R T \ln \varphi_{\mathrm{H}_{2} \mathrm{~S}}(T, P, y),
\end{aligned}
$$

where $\mu_{\mathrm{H}_{2} \mathrm{~S}}^{\nu(0)}$ is the standardization degree of $\mathrm{H}_{2} \mathrm{~S}$ in the gas phase, which is the ideal gas chemical position at a pressure of $1 \mathrm{bar} ; \mu_{\mathrm{H}_{2} \mathrm{~S}}^{l(0)}$ is the standardization degree of hydrogen sulfide in the liquid phase, which is the chemical position of the ideal solution per unit weight molar concentration; $m$ is gas solubility; $y_{\mathrm{H}_{2} \mathrm{~S}}$ is hydrogen sulfide component; $\gamma_{\mathrm{H}_{2} \mathrm{~S}}$ is hydrogen sulfide activity coefficient; $T$ is temperature; and $P$ is pressure. When the phase balance $\mu_{\mathrm{H}_{2} \mathrm{~S}}^{v}=\mu_{\mathrm{H}_{2} \mathrm{~S}}^{l}$, it can get

$$
\begin{aligned}
\ln \frac{y_{\mathrm{H}_{2} \mathrm{~S}} P}{m_{\mathrm{H}_{2} \mathrm{~S}}}= & \frac{\mu_{\mathrm{H}_{2} \mathrm{~S}}^{l(0)}(T, P)-\mu_{\mathrm{H}_{2} \mathrm{~S}}^{v(0)}(T)}{R T}-\ln \varphi_{\mathrm{H}_{2} \mathrm{~S}}(T, P, y) \\
& +\ln \gamma_{\mathrm{H}_{2} \mathrm{~S}}(T, P, m),
\end{aligned}
$$

where $\mathrm{H}_{2} \mathrm{~S}$ solubility $\left(m_{\mathrm{H}_{2} \mathrm{~S}}\right)$ is a function of the difference in $T$, $P, y_{\mathrm{H}_{2} \mathrm{~S}}, \mathrm{H}_{2} \mathrm{~S}$ fugacity coefficient $\left(\varphi_{\mathrm{H}_{2} \mathrm{~S}}\right), \gamma_{\mathrm{H}_{2} \mathrm{~S}}, \mu_{\mathrm{H}_{2} \mathrm{~S}}^{\nu(0)}$, and $\mu_{\mathrm{H}_{2} \mathrm{~S}}^{l(0)}$. Let $\mu_{\mathrm{H}_{2} \mathrm{~S}}^{v(0)}$ be zero; because only a small amount of water vapor is contained in the gas phase, the difference in the fugacity coefficient of the pure gas is very small, and the fugacity coefficient $\ln \varphi_{\mathrm{H}_{2} \mathrm{~S}}$ determined by the pure gas state equation can be approximated. Therefore, the molar fraction of $y_{\mathrm{H}_{2} \mathrm{~S}}$ in the 


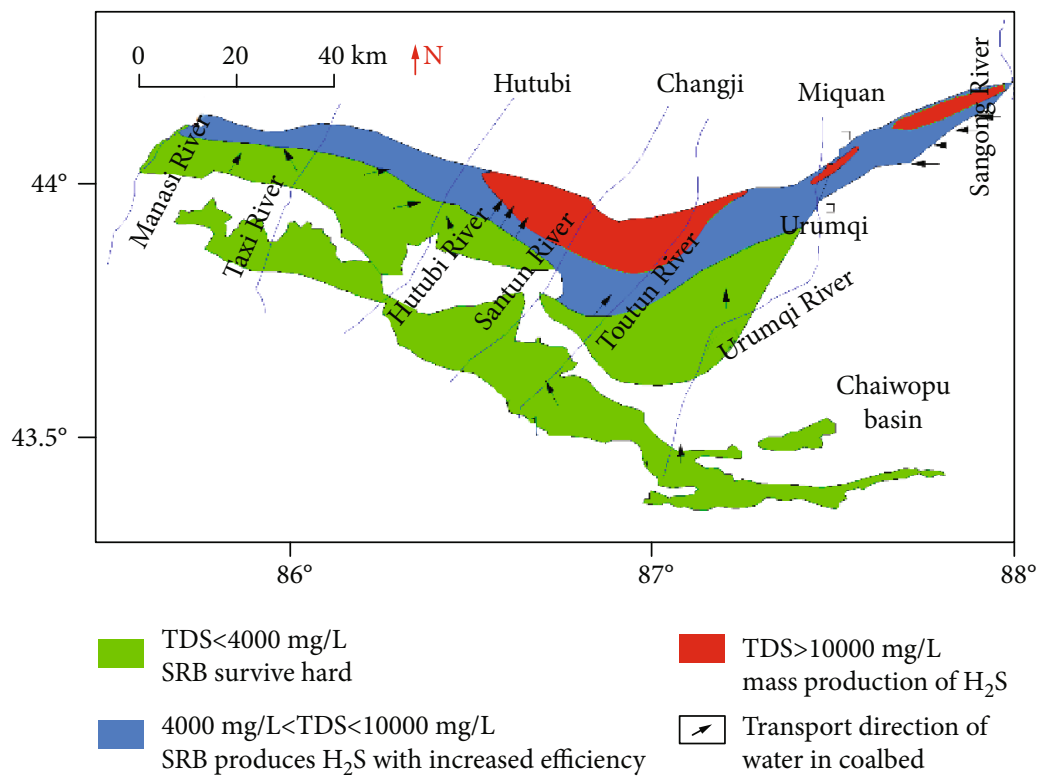

FIGURE 4: TDS distribution of groundwater and characteristics of SRB propagation and $\mathrm{H}_{2} \mathrm{~S}$ generation.

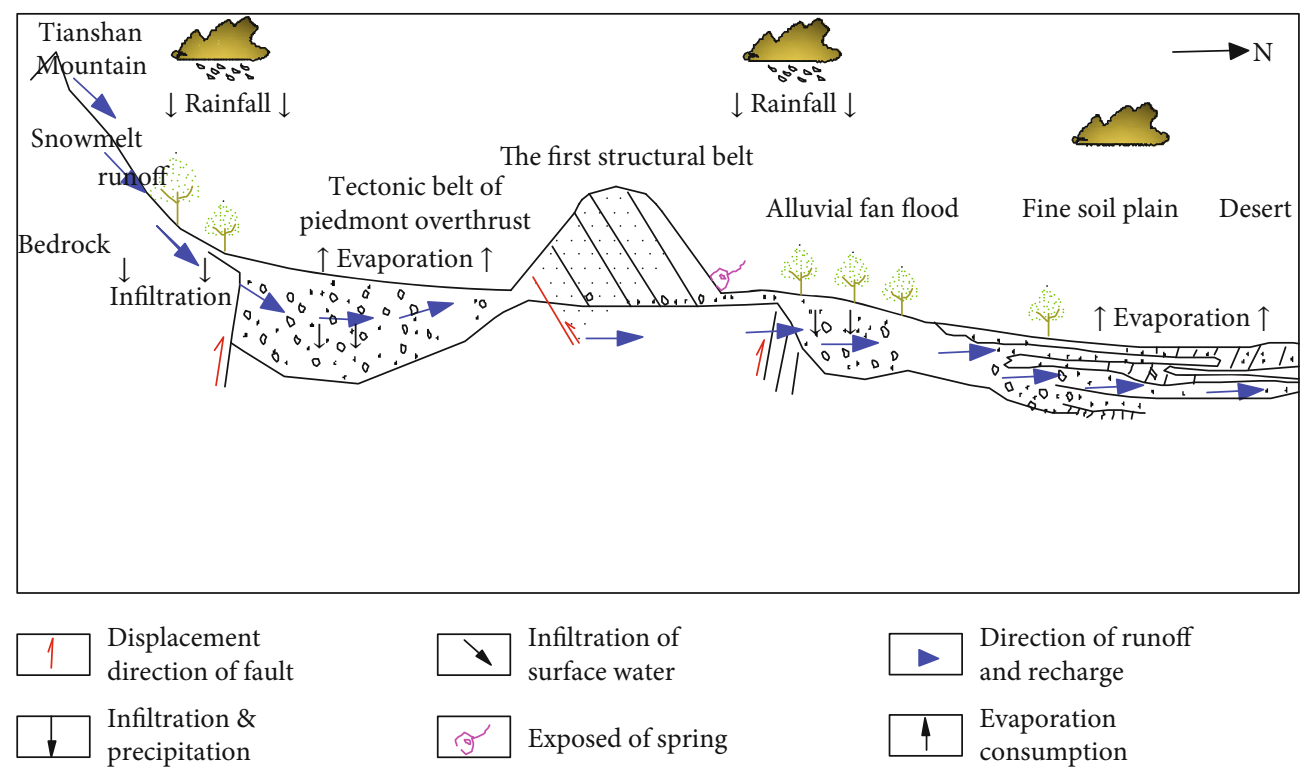

Figure 5: Cycle characteristics of water bearing $\mathrm{H}_{2} \mathrm{~S}$.

gas phase can be approximated by

$$
y_{\mathrm{H}_{2} \mathrm{~S}}=\frac{P-P_{\mathrm{H}_{2} \mathrm{O}}}{P}
$$

In the formula, $P_{\mathrm{H}_{2} \mathrm{O}}$ can be approximated as the saturation pressure of pure water. The activity coefficient of $\mathrm{H}_{2} \mathrm{~S}$ in the liquid phase can be derived from the Pitzer model [22]:

$\ln \gamma_{\mathrm{H}_{2} \mathrm{~S}}=\sum_{C} 2 \lambda_{\mathrm{H}_{2} \mathrm{~S}-C} m_{c}+\sum_{a} 2 \lambda_{\mathrm{H}_{2} \mathrm{~S}-a} m_{a}+\sum_{C} \sum_{a} \xi_{\mathrm{H}_{2} \mathrm{~S}-a-c} m_{c} m_{a}$,

where $\lambda$ and $\zeta$ are binary and ternary interaction parameters, respectively, and $c$ and $a$ represent cations and anions, respectively. Substituting Equation (10) into Equation (8) yields

$$
\begin{aligned}
\ln \frac{y_{\mathrm{H}_{2} \mathrm{~S}} P}{m_{\mathrm{H}_{2} \mathrm{~S}}}= & \frac{\mu_{\mathrm{H}_{2} \mathrm{~S}}^{l(0)}}{R T}-\ln \varphi_{\mathrm{H}_{2} \mathrm{~S}}+\sum_{C} 2 \lambda_{\mathrm{H}_{2} \mathrm{~S}-C} m_{c}+\sum_{a} 2 \lambda_{\mathrm{H}_{2} \mathrm{~S}-a} m_{a} \\
& +\sum_{C} \sum_{a} \xi_{\mathrm{H}_{2} \mathrm{~S}-a-c} m_{c} m_{a}
\end{aligned}
$$

where $\lambda, \zeta$, and the dimensionless standardized degree $\mu_{\mathrm{H}_{2} \mathrm{~S}}^{l(0)} / R T$ are all functions of temperature and pressure; these parameters can be determined by regression of 


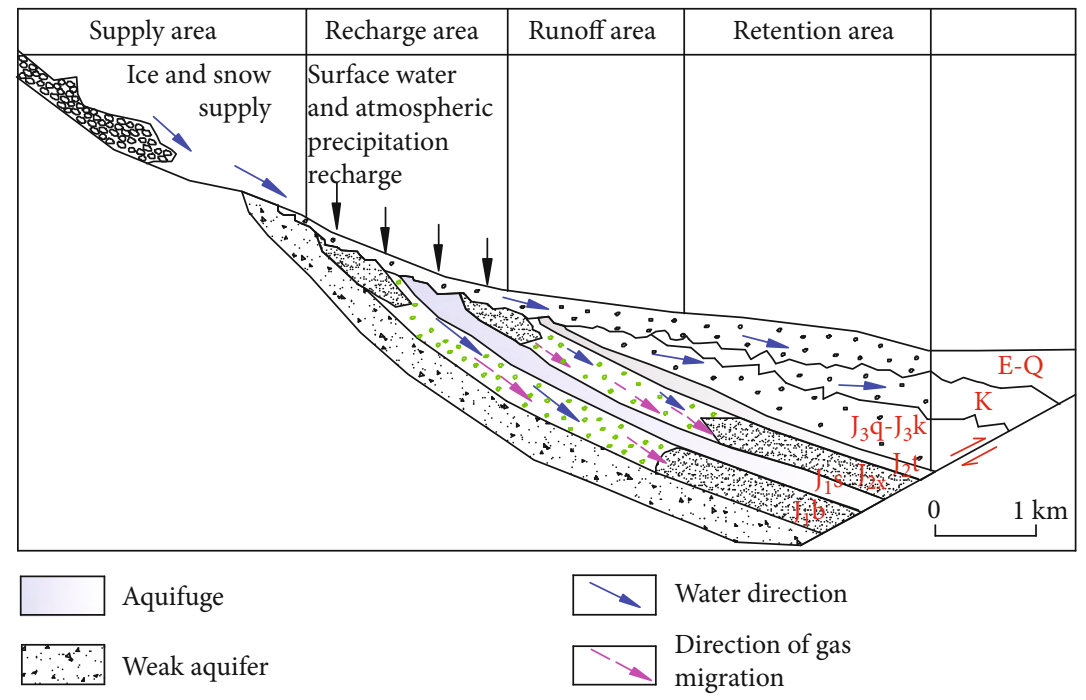

Reservior of $\mathrm{H}_{2} \mathrm{~S}$

Figure 6: Single bevel of $\mathrm{H}_{2} \mathrm{~S}$ formation and accumulation model in the east of Urumqi.

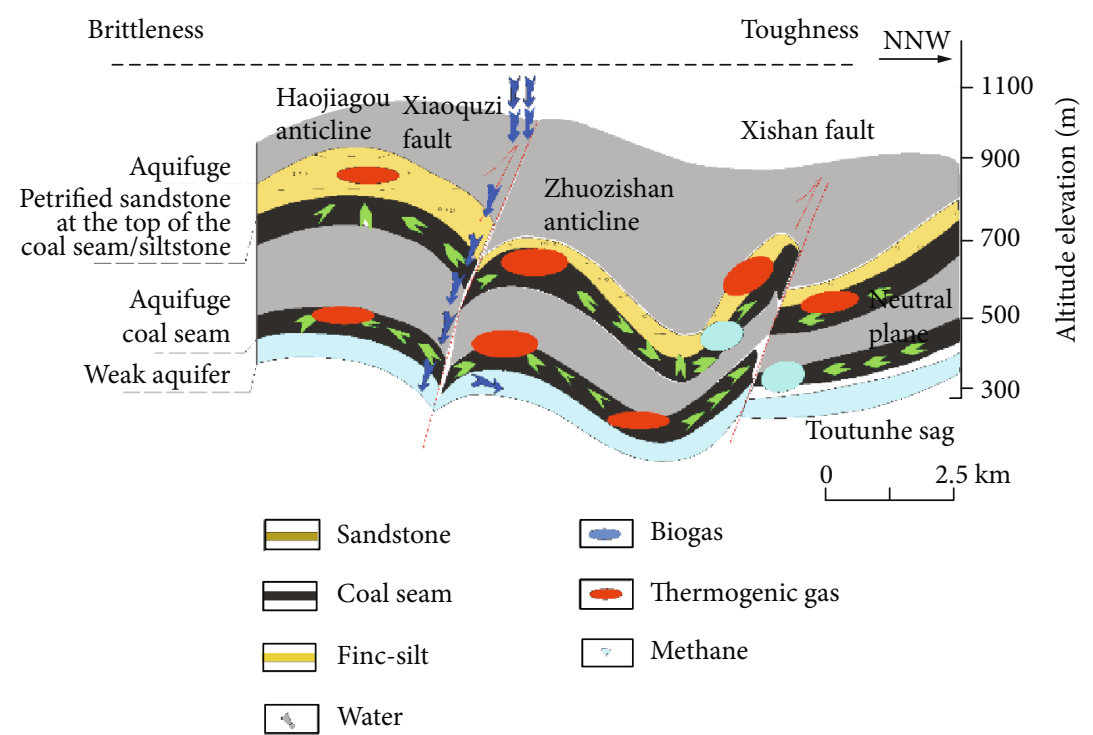

Figure 7: Imbricate of $\mathrm{H}_{2} \mathrm{~S}$ formation and accumulation model in the west of Urumqi.

solubility experimental data of pure gas. According to the Pitzer model [22], the $\mathrm{H}_{2} \mathrm{~S}$ solubility calculation model can be expressed as follows:

$$
\begin{aligned}
P \operatorname{ar}(T, P)= & C_{1}+C_{2}+\frac{C_{3}}{T}+C_{4} T^{2}+\frac{C_{5}}{680-T}+C_{6} P \\
& +\frac{C_{7} P}{680-T}+\frac{C_{8} P^{2}}{T} .
\end{aligned}
$$

Equations (11) and (12) form the basic equation for the calculation of the solubility of $\mathrm{H}_{2} \mathrm{~S}$.

The interaction parameters for calculating the solubility of $\mathrm{H}_{2} \mathrm{~S}$ were shown in Table $2[20,21]$.

According to the gas interaction parameters in Table 3, the solubility of $\mathrm{H}_{2} \mathrm{~S}$ in pure water and different molar $\mathrm{NaCl}$ and $\mathrm{Na}_{2} \mathrm{SO}_{4}$ solutions was obtained by the above formula, as shown in Figures 8-10 [20, 21, 23-25].

It can be seen that under the same conditions, the solubility of $\mathrm{H}_{2} \mathrm{~S}$ in pure water is greater than that of aqueous solution containing salinity, and its solubility decreases as the temperature of the solution rises. The higher the degree of mineralization, the lower the solubility of hydrogen sulfide. With the increase of pressure, the solubility of hydrogen sulfide can be significantly improved, especially in the initial stage of $0.1 \mathrm{MPa} \sim 6.0 \mathrm{MPa}$.

Studies have shown that the variation law of the regional geothermal gradient is the following [16]: when the buried depth is less than $1000 \mathrm{~m}$, it is between $24^{\circ} \mathrm{C}$ and $41^{\circ} \mathrm{C}$, with an average of $33^{\circ} \mathrm{C}$; the buried depth is $1000 \mathrm{~m} 2000 \mathrm{~m}$, which is between $34^{\circ} \mathrm{C}$ and $73^{\circ} \mathrm{C}$; the average is $53.8^{\circ} \mathrm{C}$. According to the reservoir parameters of the $1000 \mathrm{~m}$ 
TABLE 2: Interaction parameters of $\mathrm{H}_{2} \mathrm{~S}$ solubility.

\begin{tabular}{|c|c|c|c|}
\hline$T-P$ coefficient & $\frac{\mu_{\mathrm{H}_{2} \mathrm{~S}}^{1(0)}}{R T}$ & $\lambda_{\mathrm{H}_{2} \mathrm{~S}-\mathrm{Na}}$ & $\zeta_{\mathrm{H}_{2} \mathrm{~S}-\mathrm{Na}-\mathrm{Cl}}$ \\
\hline$C_{1}$ & 42.564957 & $8.5004999 \times 10^{-2}$ & $-1.0832589 \times 10^{-2}$ \\
\hline$C_{2}$ & $-8.6260377 \times 10^{-2}$ & $3.5330 .78 \times 10^{-5}$ & \\
\hline$C_{3}$ & -6084.3775 & -1.5882605 & \\
\hline$C_{4}$ & $6.8714437 \times 10^{-5}$ & & \\
\hline$C_{5}$ & -102.76849 & & \\
\hline$C_{6}$ & $8.4482895 \times 10^{-4}$ & $1.1894926 \times 10^{-5}$ & \\
\hline$C_{7}$ & -1.0590768 & & \\
\hline$C_{8}$ & $3.5665902 \times 10^{-3}$ & & \\
\hline
\end{tabular}

TABLE 3: Reservoir parameters of $1000 \mathrm{~m}$ depth of coal measures and solubility of $\mathrm{H}_{2} \mathrm{~S}$ in the region.

\begin{tabular}{lcccc}
\hline Hydrogeological unit & Formation temperature $\left({ }^{\circ} \mathrm{C}\right)$ & Reservoir pressure $(\mathrm{MPa})$ & Salinity $(\mathrm{mg} / \mathrm{L})$ & Solubility of $\mathrm{H}_{2} \mathrm{~S}(\mathrm{mg} / \mathrm{L})$ \\
\hline Manasi River-Hutubi River & 32.3 & 8.9 & 2100 & 54200 \\
Liuhuangou area & 35.2 & 9.1 & 11500 & 49680 \\
Miquan area & 32.6 & 8.8 & 10800 & 50320 \\
Houxia area & 28.3 & 9.8 & 1210 & 59840 \\
\hline
\end{tabular}

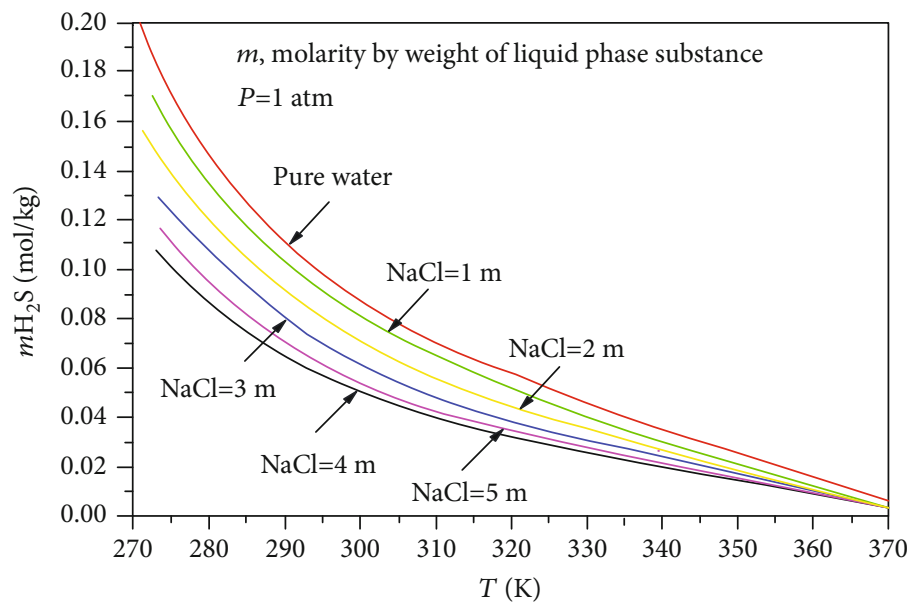

FIGURE 8: Solubility of $\mathrm{H}_{2} \mathrm{~S}$ in pure water and $\mathrm{NaCl}$ solution.

reservoir depth of the four hydrogeological units, the solubility of $\mathrm{H}_{2} \mathrm{~S}$ in the groundwater in coal measures can be estimated, as shown in Table 3. And the characteristics of SRB propagation and hydrogen sulfide production in the region are shown in Figure 4.

\section{Conclusions}

(1) Four hydrogeological units are divided. The salinity in the hydrogeological units is low, where hydraulic power alternates strongly; it is not conducive to the survival of SRB and the formation of hydrogen sulfide. The high salinity center and depressions of low water level (hydrodynamic stagnation zone) are the main areas for the proliferation of SRB and pro- duction and enrichment of $\mathrm{H}_{2} \mathrm{~S}$ in the low-rank coal. The increase in salinity is conducive to the proliferation of SRB and the formation of hydrogen sulfide

(2) The deep confined water environment closed well; under the action of SRB, BSR will occur and $\mathrm{H}_{2} \mathrm{~S}$ can form. Imbricate and single bevel two kind generation and enrichment mode of hydrogen sulfide under the hydrodynamic control was obtained

(3) In calculating the solubility of hydrogen sulfide gas in the groundwater in coal measures, in addition to the factors mentioned in the paper, it should be considered in combination with the chemical type of formation water and the characteristics of mixed gas components 

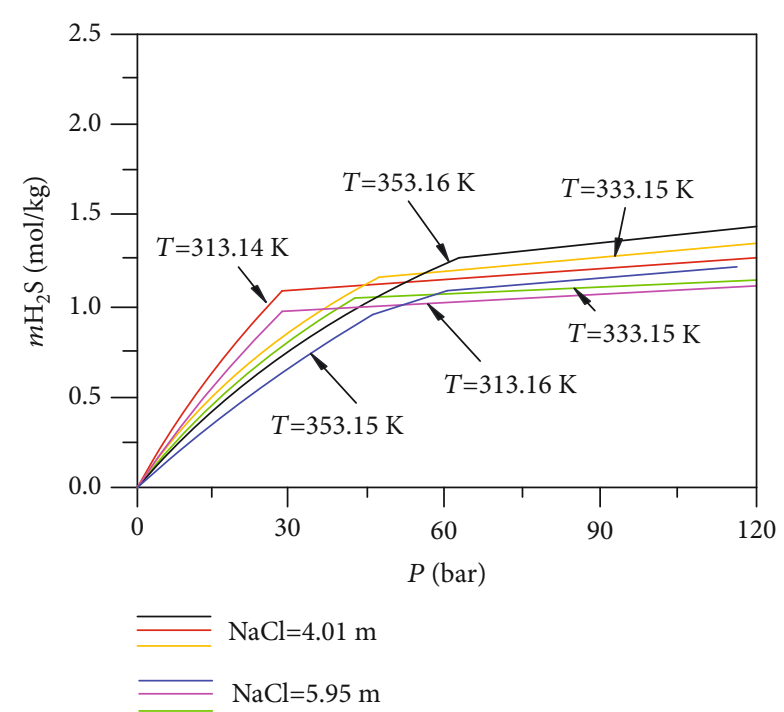

FIGURE 9: Solubility of $\mathrm{H}_{2} \mathrm{~S}$ in $\mathrm{NaCl}$ solution.

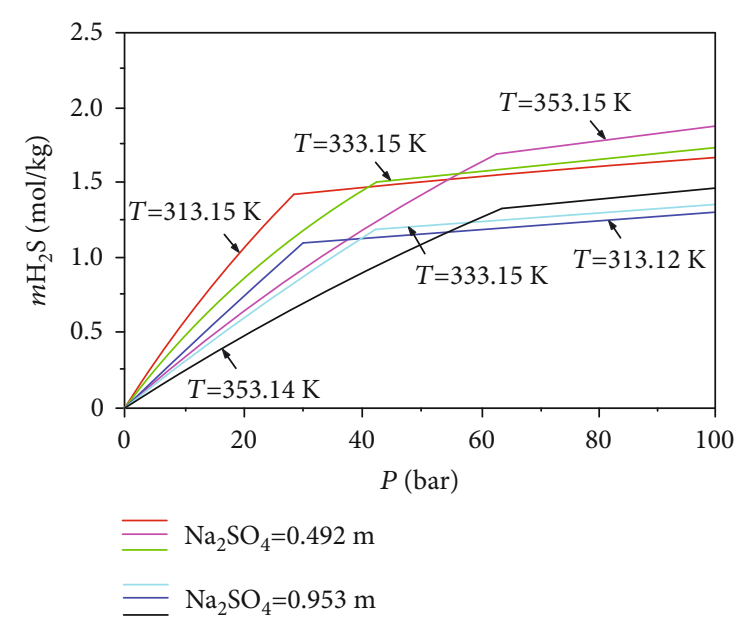

FIgURE 10: Solubility of $\mathrm{H}_{2} \mathrm{~S}$ in $\mathrm{Na}_{2} \mathrm{SO}_{4}$ solution.

\section{Data Availability}

The data used to support the findings of this study are available from the corresponding author upon request.

\section{Conflicts of Interest}

The authors declare that they have no conflicts of interest.

\section{Acknowledgments}

The authors are grateful to Professor Mingju Liu of Henan Polytechnic University for his ardent guidance and help. This work was supported by the National Natural Science Foundation of China under grant No. 51774116, the Key Scientific Research Project of Colleges and Universities in Henan Province under grant No. 14B440006, and the Training Plan of Young Backbone Teachers in Colleges and Universities of Henan Province under grant No. 2019GGJS052.

\section{References}

[1] Q. Deng, J. Yin, X. Wu, T. Zhang, H. Wang, and M. Liu, "Research advances of prevention and control of hydrogen sulfide in coal mines," The Scientific World Journal, vol. 2019, Article ID 8719260, 15 pages, 2019.

[2] Q. Deng, X. Wu, Y. Wang, and M. Liu, "Activity characteristics of sulfate reducing bacteria and formation mechanism of hydrogen sulphide," Applied Ecology and Environmental Research, vol. 16, no. 5, pp. 6369-6383, 2018.

[3] H. G. Machel, "Bacterial and thermochemical sulfate reduction in diagenetic settings - old and new insights," Sedimentary Geology, vol. 140, no. 1-2, pp. 143-175, 2001.

[4] M. Liu, Q. Deng, F. Zhao, and Y. Liu, "Origin of hydrogen sulfide in coal seams in China," Safety Science, vol. 50, no. 4, pp. 668-673, 2012.

[5] Q. Deng, M. Liu, X. Cui, and J. Wen, "A study of hydrogen sulfide genesis in coal mine of southeastern margin of Junggar basin," Journal of Earth Science Frontiers, vol. 24, no. 5, pp. 395-401, 2017.

[6] Y. Li, C. Zhang, D. Tang et al., "Coal pore size distributions controlled by the coalification process: An experimental study of coals from the Junggar, Ordos and Qinshui basins in China," Fuel, vol. 206, pp. 352-363, 2017.

[7] S. Tao, Z. Pan, S. Chen, and S. Tang, "Coal seam porosity and fracture heterogeneity of marcolithotypes in the Fanzhuang block, southern Qinshui Basin, China," Journal of Natural Gas Science and Engineering, vol. 66, pp. 148-158, 2019.

[8] J. J. Tian and S. G. Yang, "Sequence strata and coal accumulation of lower and middle Jurassic formation from southern margin of Junggar Basin, Sinkiang, China," Journal of China Coal Society, vol. 36, no. 1, pp. 58-64, 2011.

[9] Y. Li, J. Yang, Z. Pan, S. Meng, K. Wang, and X. Niu, "Unconventional natural gas accumulations in stacked deposits: a discussion of Upper Paleozoic coal-bearing strata in the east margin of the Ordos Basin, China," Acta Geologica Sinica, vol. 93, no. 1, pp. 111-129, 2019.

[10] L. Yong, C. Daiyong, W. Yingchun, W. Anmin, Z. Qiang, and W. Peng, "Middle to low rank coalbed methane accumulation and reservoiring in the southern margin of Junggar Basin," Acta Petrolei Sinica, vol. 37, no. 12, pp. 1472-1482, 2016.

[11] Z. H. Chen, Z. P. Meng, and L. J. Zeng, "Formation mechanism and enrichment patterns of middle-low rank coalbed methane in southern Junggar Basin, China," Journal of China Coal Society, vol. 42, no. 12, pp. 3203-3211, 2017.

[12] L. Duan, W. K. Wang, Y. Q. Cao, L. J. Wang, and B. Liu, "Hydrochemical characteristics and formation mechanics of groundwater in the middle of northern slope of Tianshan Mountains," Journal of Arid Land Resources and Environment, vol. 21, no. 9, pp. 29-34, 2007.

[13] J. Guo, X. Wang, and X. Pang, "Evaluaton and hydrocarbon expulsion characteristics of the middle-lower Jurassic source rock in the southern margin of Junggar basin," Journal of China University of Ming \& Technology, vol. 42, no. 4, pp. 595-605, 2013.

[14] S. Tao, S. Chen, and Z. Pan, "Current status, challenges, and policy suggestions for coalbed methane industry development in China: a review," Energy Science \& Engineering, vol. 9, no. 7, pp. 1-16, 2019.

[15] C. Z. Jia, "Foreland thrust-fold belt features and gas accumulation in Midwest China," Petroleum Exploration \& Development, vol. 32, no. 4, pp. 9-15, 2005. 
[16] D. Y. Yu, F. M. Peng, X. W. Liu, and J. L. Zheng, "Effect of environment on the growth of sulfate reducing bacteria," Materiais Protection, vol. 29, no. 2, pp. 1-2, 1996.

[17] Q. Deng, J. Wei, H. Li, Y. Wang, X. Wu, and M. Liu, "Hydrogen sulfide accumulation factors in coal mine of southeastern margin of Junggar basin in China," Applied Ecology and Environmental Research, vol. 17, no. 1, pp. 683-697, 2019.

[18] L. Zhang and R. Sun, "An improved thermodynamic model for calculating solubility of the $\mathrm{CO}_{2}-\mathrm{CH}_{4}-\mathrm{N}_{2}-\mathrm{C}_{2} \mathrm{H}_{6}-\mathrm{H}_{2} \mathrm{~S}$ gas mixture in water," Geological Journal of China Universities, vol. 22, no. 4, pp. 589-597, 2016.

[19] S. Mao, L. Shi, Q. Peng, and M. Lü, "Thermodynamic modeling of binary $\mathrm{CH}_{4}-\mathrm{CO}_{2}$ fluid inclusions," Applied Geochemistry, vol. 66, no. 20, pp. 65-72, 2016.

[20] Z. Duan, R. Sun, R. Liu, and C. Zhu, "Accurate thermodynamic model for the calculation of $\mathrm{H}_{2} \mathrm{~S}$ solubility in pure water and brines," Energy \& Fuels, vol. 21, no. 4, pp. 2056-2065, 2007.

[21] Z. H. Duan and Q. Wei, "Model for the calculation of the solubility of $\mathrm{CH}_{4}: \mathrm{H}_{2} \mathrm{~S}$ and $\mathrm{CO}_{2}$ in aqueous solutions," Acta Geologica Sinica, vol. 85, no. 7, pp. 1079-1093, 2011.

[22] K. S. Pitzer, J. C. Peiper, and R. H. Busey, "Thermodynamic properties of aqueous sodium chloride solutions," Journal of Physical and Chemical Reference Data, vol. 13, no. 1, pp. 1102, 1984.

[23] J. I. Lee and A. E. Mather, "Solubility of hydrogen sulfide in water," Berichte der Bunsengesellschaft für physikalische Chemie, vol. 81, no. 10, pp. 1020-1023, 1977.

[24] S. Ingolf and C. H. Whitson, "Peng-Robinson predictions for hydrocarbons, $\mathrm{CO}_{2}, \mathrm{~N}_{2}$, and $\mathrm{H}_{2} \mathrm{~S}$ with pure water and $\mathrm{NaCl}$ brine," Fluid Phase Equilibria, vol. 77, no. 92, pp. 217-240, 1992.

[25] B. Rumpf, Á. Pérez-Salado Kamps, R. Sing, and G. Maurer, "Simultaneous solubility of ammonia and hydrogen sulfide in water at temperatures from $313 \mathrm{~K}$ to $393 \mathrm{~K}$," Fluid Phase Equilibria, vol. 158-160, no. 9, pp. 923-932, 1999. 